\title{
Synthesis of Sulfonylated 4-Amino-1H-Pyrazoles with Aryl and Methoxymethyl Substituents
}

\author{
Ilya G. Povarov*, \\ Alexey V. Lyubyashkin, Anna S. Kositsyna, \\ Georgy A. Suboch and Mikhail S. Tovbis \\ Siberian State University \\ 31 Krasnoyarsky Rabochy, Krasnoyarsk, 660037, Russia
} Science and Technology named after academician M.F. Reshetnev

Received 14.03.2017, received in revised form 26.06.2017, accepted 07.08.2017

The experimental data on the sulfonylation of 4-amino-1H pyrazoles with p-toluenesulfonyl chloride are given in the paper. New compounds were obtained: 3,5-dimethyl-4-tosylamino-1H-pyrazole, 3-methoxymethyl-5-phenyl-4-tosylamino-1H-pyrazole, 3-methoxymethyl-5-naphthyl-4-tosylamino1H-pyrazole, 3-methyl-5-naphthyl-4-tosylamino-1H-pyrazole. The structure of sulfonylated aminopyrazoles was proved by IR, UV, $1 H$ NMR spectroscopy and mass spectrometry.

Keywords: pyrazole, aminopyrazole, sulfonylamide, sulfonylation, NMR, IR, UV spectroscopy, mass spectrometry.

DOI: $10.17516 / 1998-2836-0026$.

(C) Siberian Federal University. All rights reserved

* Corresponding author E-mail address: povarov_i@mail.ru 


\title{
Синтез сульфонилированных 4-амино-1Н-пиразолов
}

\section{с арильными и метоксиметильными заместителями}

\author{
И.Г. Поваров, А.В. Любяшкин, \\ А.С. Косицына, Г.А. Субоч, М.С. Товбис \\ Сибирский государственный университет
} науки и технологий имени академика М.Ф. Решетнева Россия, 660037, Красноярск, пр. имени газеты «Красноярский рабочий», 31

В статье приведены экспериментальные данные по сульфонилированию 4-амино-1Н пиразолов n-толуолсульфохлоридом. Получены новые соединения: 3,5-диметил-4-тозиламино-1Hпиразол, 3-метоксиметил-5-фенил-4-тозиламино-1Н-пиразол, 3-метоксиметил-5-нафтил4-тозиламино-1Н-пиразол, 3-метил-5-нафтил-4-тозиламино-1Н-пиразол. Строение сульфонилированных аминопиразолов доказано с помощью ИК, УФ, ЯМРІН спектроскопии и масс-спектрометрии.

Ключевые слова: пиразол, аминопиразол, сульфониламид, сульфонилирование, ЯМРІН-, ИК-, УФ-спектроскопия, масс-спектрометрия.

\section{Introduction}

An important priority for a person is to maintain healthy. Nowadays, there is a huge number of medicines in the world, but microbes progress with a great speed, constantly adapting to the activity of new drugs, and therefore the search and synthesis of new substances with antibacterial activity does not stop.

It is known that among the pyrazole derivatives there are a number of known highly effective drugs, such as antipyrine, analgin and others [1]. Therefore, new pyrazole derivatives by now continue to attract the attention of specialists engaged in the search for new effective biologically active substances, including chemical-pharmaceutical drugs, pesticides, bioprotectors for various materials, antioxidants, etc. Particularly interesting ones in this respect are amine-substituted pyrazoles. The disadvantages of known aminopyrazoles include their poor solubility and as a consequence the difficulty of removing the products of their metabolism from the body therefore they are toxic to the liver and kidneys, and also cause the manifestation of agranulocytosis [2].

Most often, amines are not used in a free form, but in the form of sulfonylated derivatives. So, sulfanilamide drugs are very widely used - a group of chemically synthesized compounds used for the treatment of infectious diseases, mainly of bacterial origin.

Sulfanilamides were the first drugs that allowed successful prevention and treatment of a variety of bacterial infections. Thanks to these drugs entered into medical practice since the 1930s, it was possible to significantly reduce the death rate from pneumonia, blood infection and many other bacterial infections. Their widespread use during the World War II saved many lives [3].

Therefore, the aim of our work was to obtain new sulfonyl derivatives of aminopyrazoles. Earlier at the department of organic chemistry and technology of organic substances, aminopyrazoles with aryl 
and methoxymethyl substituents were obtained and characterized. Proceeding from this, we decided to synthesize previously unknown p-toluenesulfonyl (tosyl) derivatives of aminopyrazoles [4].

\section{Materials and methods}

The synthesis was carried out according to the scheme given below, carrying out the tosylation of various substituted aminopyrazoles [5], which may have biological activity. The synthesis scheme is shown in Fig. 1.

To carry out the synthesis, $0.1 \mathrm{~g}$ of substituted aminopyrazole and $4 \mathrm{ml}$ of water were charged into a flask equipped with a magnetic stirrer. The mixture was stirred and heated to $60{ }^{\circ} \mathrm{C}$. For 1 hour, $0.3 \mathrm{~g}$ of $p$-toluenesulfochloride and $0.1 \mathrm{~g}$ of sodium carbonate were added alternately in small portions, making sure that the reaction of the medium was neutral. The mixture was then stirred for 2 hours, and cooled down to room temperature. To purify from the original aminopyrazole, concentrated hydrochloric acid was added dropwise to the reaction mixture before the acidic Congo reaction, and the mixture was stirred for an additional 30 minutes at room temperature. The resulting precipitate was filtered off and washed with water from the acid to a neutral reaction, then dried under vacuum. Thin-layer chromatogram (TLC) in the eluent, toluene-ethyl acetate (1:1) showed the individuality of the products.

\section{Results and discussion}

The yield of 3,5-dimethyl-4-tosylamino-1H-pyrazole (I) was $68 \%$, m.p. is $196-198{ }^{\circ} \mathrm{C}$, TLC in the eluent of toluene-ethyl acetate (1:1) showed the individuality of the product. In the UV spectrum, there was a maximum absorption at the wavelength (ethanol): $\lambda \max =224 \mathrm{~nm}, \varepsilon=632 ; \lambda \max =317 \mathrm{~nm}$, $\varepsilon=96$. Mass Spectrum m/z: $\mathrm{M}^{+}$(265) 264 (100), 155(53), 91(68), 65(11), 42(15)

1H NMR spectrum is shown in Fig. 2.

In the NMR spectrum in a weak field, signals are present ppm: $9.41 \mathrm{~s}(1 \mathrm{H}, \mathrm{NH}), 7.26-7.73$ (4H tosyl ring), 2.38-2.43 s ( $3 \mathrm{H}, \mathrm{CH}_{3}$ tosyl ring), $1.70-1.94 \mathrm{~s}\left(6 \mathrm{H}, 2 \mathrm{CH}_{3}\right.$ of the pyrazole ring). In the IR spectrum, a band of the stretching vibration of the $\mathrm{SO}_{2}$ group is observed in the region of $1163 \mathrm{~cm}^{-1}$. In the region of $3246 \mathrm{~cm}^{-1}$, vibrations of the free $\mathrm{NH}$ group are observed.

The yield of 3-methoxymethyl-5-phenyl-4-tosylamino-1H-pyrazole (II) was 40\%. m.p. 170$172{ }^{\circ} \mathrm{C}$, TLC in the eluent of toluene-ethyl acetate $(1: 1)$ showed the individuality of the product. In the
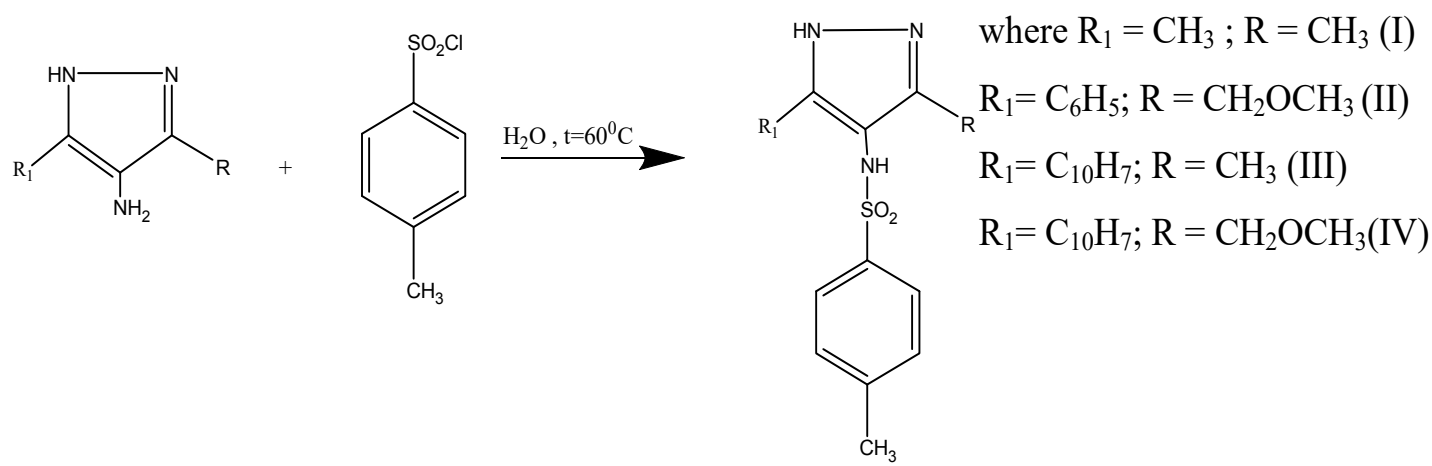

Fig. 1. Scheme for the preparation of sulfonylated derivatives 


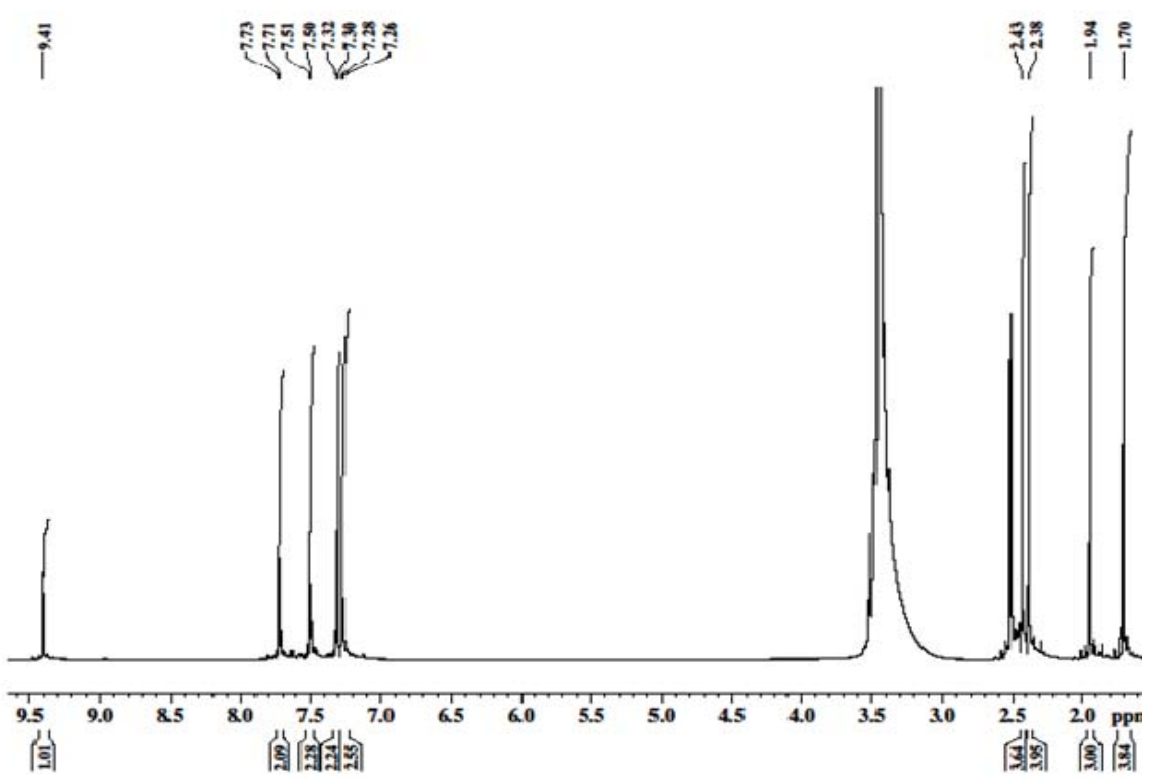

Fig. 2. NMR spectrum of 3,5-dimethyl-4-tosylamino-1H-pyrazole in DMSO-d $\mathrm{d}_{6}$

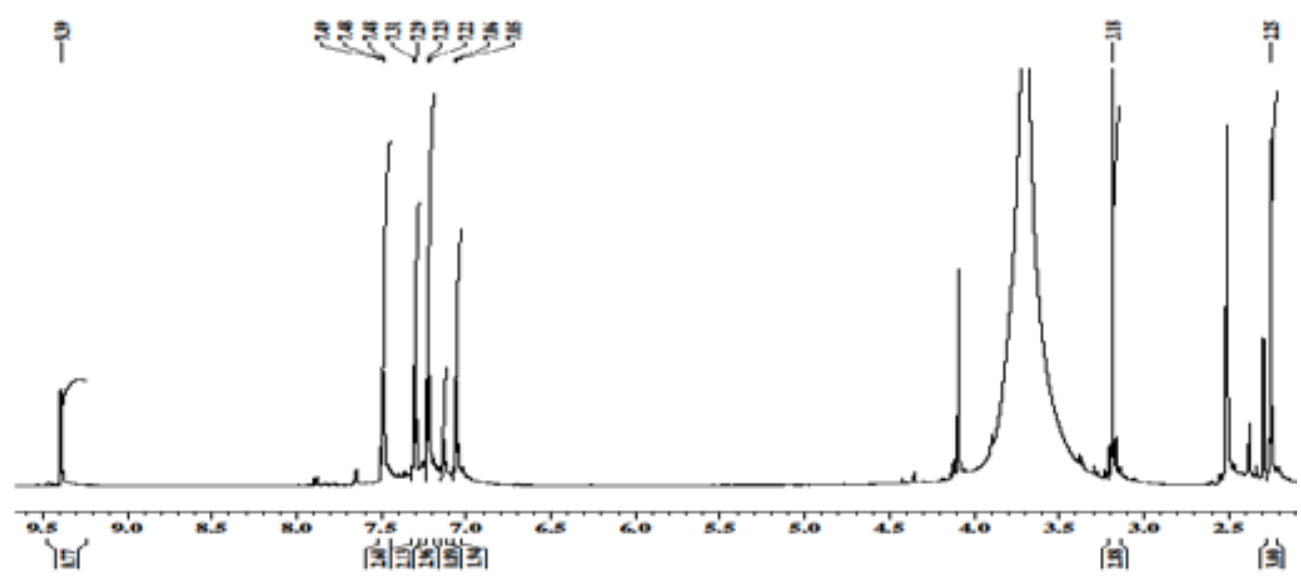

Fig. 3. NMR spectrum of 3-methoxymethyl-5-phenyl-4-tosylamino-1H-pyrazole in DMSO-d 6

UV spectrum there was a maximum absorption at the wavelength (ethanol): $\lambda \max =235 \mathrm{~nm}, \varepsilon=694$; $\lambda \max =352 \mathrm{~nm}, \varepsilon=117$. Mass Spectrum m/z: $\mathrm{M}^{+}$(357) 357 (100), 202(47), 172(43), 104(15), 91(30), $65(12)$

1H NMR spectrum is shown in Fig. 3.

In the NMR spectrum in a weak field, signals are present ppm: $9.39 \mathrm{~s}(1 \mathrm{H}, \mathrm{NH}), 7,05-7,49 \mathrm{~m}(11 \mathrm{H}$, tosyl and the naphthalene rings) $3.18\left(2 \mathrm{H}, \mathrm{CH}_{2}\right), 2.25 \mathrm{~s}\left(3 \mathrm{H}, \mathrm{CH}_{3}\right)$. In the IR spectrum, a band of the stretching vibration of the $\mathrm{SO}_{2}$ group is observed in the region of $1157 \mathrm{~cm}^{-1}$. In the region of $2359 \mathrm{~cm}^{-1}$, vibrations of the free NH group are observed.

The yield of 3-methyl-5-naphthyl-4-tosylamino-1H-pyrazole (III) was 80\%, m.p. $=160-163{ }^{\circ} \mathrm{C}$. A thin layer chromatogram in the eluent of toluene-ethyl acetate (1:1) showed the individuality of the 


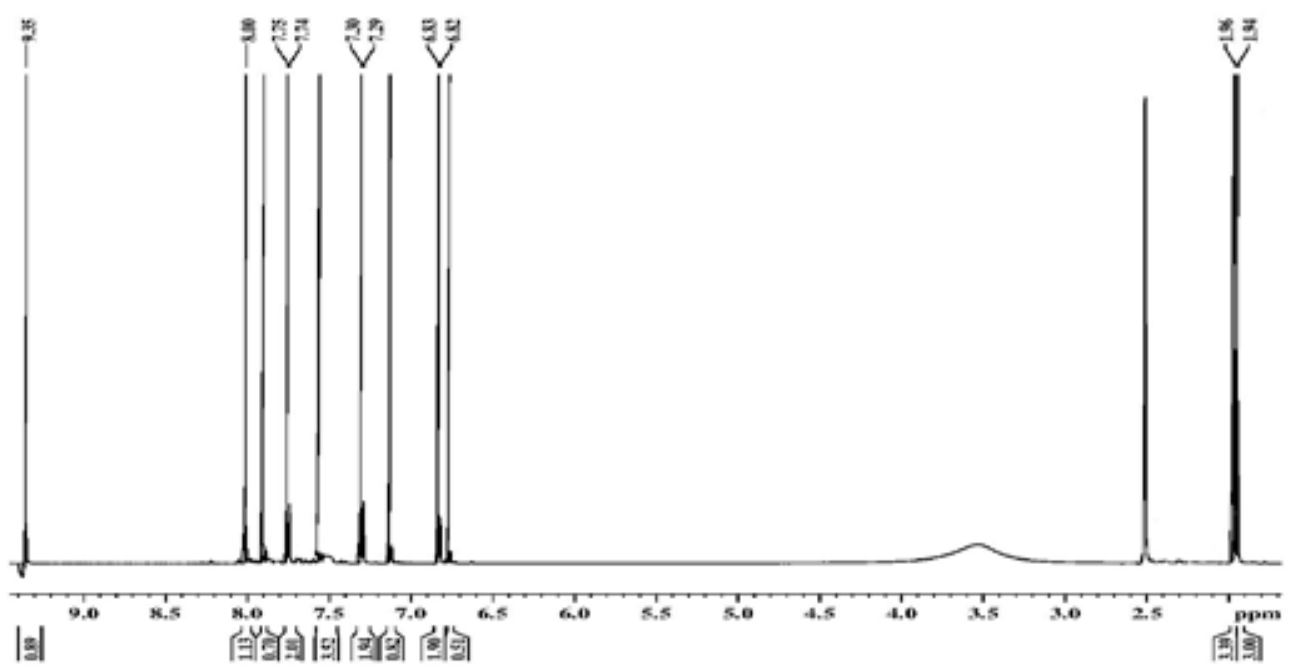

Fig. 4. NMR spectrum of 3-methyl-5-naphthyl-4-tosylamino-1H-pyrazole in DMSO-d 6

product. In the UV spectrum, there was a maximum absorption at the wavelength: $\lambda \max =232 \mathrm{~nm}$ (ethanol) with a molar extinction coefficient $\varepsilon=351$. Mass Spectrum m/z: $\mathrm{M}^{+}$(377) 377 (100), 222(88), 205(24), 195(26), 154(35), 127(31), 91(35), 65(11), 42(15)

The 1H NMR spectrum is shown in Fig. 4.

In the NMR spectrum in a weak field, there is a singlet of the proton NH group of the pyrazole ring $\delta=9.35 \mathrm{ppm}$, seven protons of the naphthalene ring and four protons of the tosyl ring with the chemical shift $\delta=6.82-8.00(\mathrm{~m}) \mathrm{ppm}$, the signal of three protons $\mathrm{CH}_{3}$ of the tosyl ring group $\delta=1.96 \mathrm{ppm}$ and three protons of the $\mathrm{CH}_{3}$ group of the pyrazole ring, $\delta=1.94 \mathrm{ppm}$. In the IR spectrum, a band of the stretching vibration of the $\mathrm{SO}_{2}$ group is observed in the region of $1162 \mathrm{~cm}^{-1}$. In the region of $3264 \mathrm{~cm}^{-1}$, vibrations of the free $\mathrm{NH}$ group are observed.

The yield of 3-methoxymethyl-5-naphthyl-4-tosylamino-1H-pyrazole (IV) was 77\%, m.p. $=141-144{ }^{\circ} \mathrm{C} . \mathrm{TLC}$ in toluene-ethyl acetate (1:1) eluent showed the individuality of the product. In the UV spectrum, there was a maximum absorption at the wavelength: $\lambda \max =235 \mathrm{~nm}$ (ethanol) $\varepsilon=694$ and $\lambda \max =352 \mathrm{~nm}$ and (ethanol) $\varepsilon=108$. Mass Spectrum $\mathrm{m} / \mathrm{z}: \mathrm{M}^{+}$(407) 407 (100), 252(73), 220(90), 192(17), 154(26), 127(24), 91(33), 65(11), 45(15)

1H NMR spectrumis shown in Fig. 5.

In the NMR spectrum in a weak field, there is a proton singlet of the NH group of the pyrazole ring $\delta=9.52 \mathrm{ppm}$, eleven protons of the naphthalene and tosyl rings with the chemical shift $\delta=6.74$ 7.95 (m) ppm, two $\mathrm{CH}_{2}$ protons with the chemical shift $\delta=4.28 \mathrm{ppm}$, the signal of three protons of the $\mathrm{CH}_{3}$ group of the tosyl ring $\delta=3.26 \mathrm{ppm}$ and three protons of the $\mathrm{CH}_{3}$ group of the pyrazole ring $\delta=1.88 \mathrm{ppm}$. In the IR spectrum, a band of the stretching vibration of the $\mathrm{SO}_{2}$ group is observed in the region of $1198 \mathrm{~cm}^{-1}$. In the region of $2995 \mathrm{~cm}^{-1}$, vibrations of the free $\mathrm{NH}$ group are observed.

\section{Conclusion}

1) General methodological principles for the synthesis of new p-toluenesulfonyl (tosyl) derivatives of aminopyrazoles have been developed. 


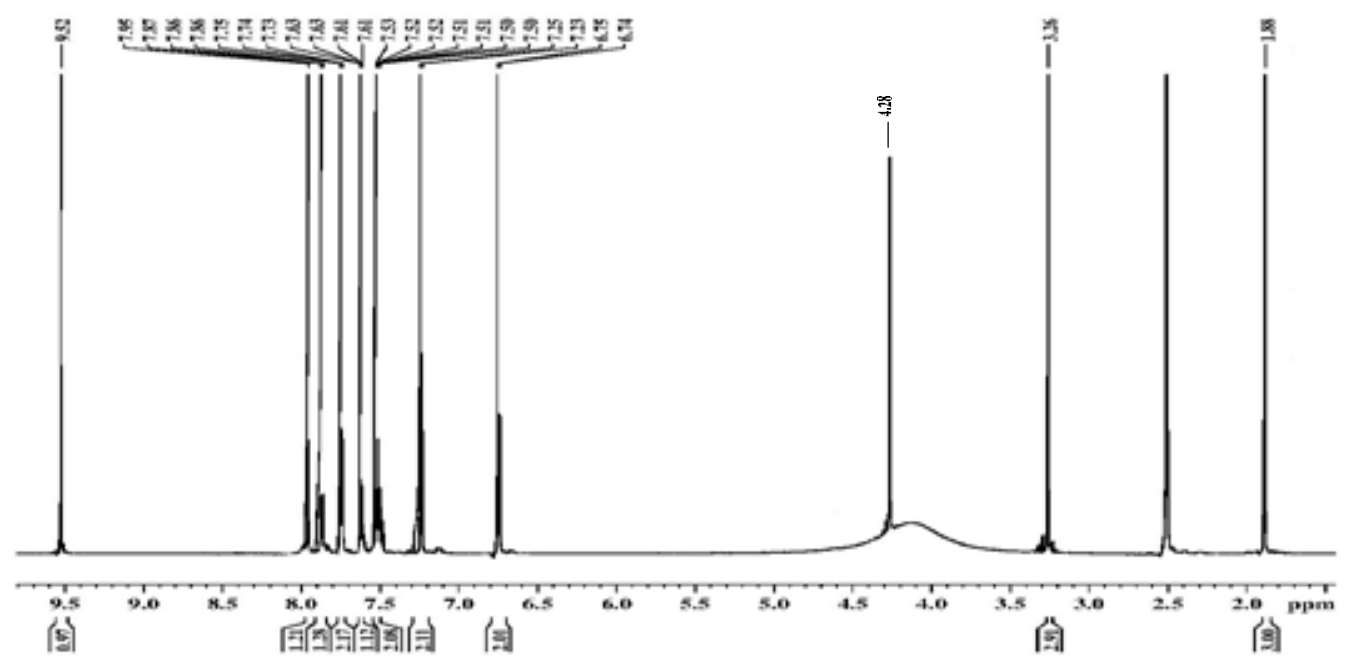

Fig. 5. NMR spectrum of 3-methoxymethyl-5-naphthyl-4-tosylamino-1H-pyrazole in DMSO-d 6

2) As a result of the work, four new previously unknown multifunctional aminopyrazoles were synthesized.

3) The structure of all newly synthesized compounds has been proved with the help of modern methods of spectral analysis: 1H NMR, IR, UV spectroscopy and mass spectrometry.

\section{References}

1. Данилов Е.А., Исляйкин М.К. Введение в химию и технологию химико-фармацевтических препаратов. Иваново: под ред. Г.П. Шапошникова, 2002. 284 с. [Danilov E.A., Islyaikin M.К. Introduction to Chemistry and Technology of Chemical-Pharmaceutical Preparations, Ivanovo: Ed. G.P. Shaposhnikova, 2002. 284 p. (In Russ.)]

2. Sharshira, E.M.; Hamada, N.M.M. Synthesis and Antimicrobial Evaluation of Some Pyrazole Derivatives. Molecules, 2012, 17, 4962-4971.

3. Машковский М.Д. Лекарственные средства. В 2-х частях. 14-е изд., перераб. и доп. М.: Медицина, 2000. T. 1.736 с. T. 2.688 c. [Mashkovsky M.D. Medicinal products. In 2 parts. 14 th ed., rev. M.: Medicine, 2000. Vol. 1. 736 p. 2. 688 p. (In Russ.)]

4. Любяшкин А.В., Петерсон И.В., Субоч Г.А. Синтез этоксиметилнитрозопиразолов. Журнал органической химии. 2015. Т. 51. № 4. С. 607-608 [Lyubiashkin A.V., Peterson I.V., Suboch G.A. Synthesis of ethoxymethylnitrosopyrazoles. Journal of Organic Chemistry. 2015. Vol. 51. No. 4. P. 607-608. (In Russ.)]

5. Ефимов В.В., Любяшкин А.В., Субоч Г.А. Синтез новых алкоксиметилзамещенных 4-амино-1Н-пиразолов и их ацилирование. Журнал органической химии. 2016. Т. 56. С. 52-54 [Efimov V.V., Lyubiashkin A.V., Suboch G.A. Synthesis of new alkoxymethyl-substituted 4-amino-1Hpyrazoles and their acylation. Journal of Organic Chemistry. 2016. Vol. 56. P. 52-54. (In Russ.)] 